\title{
Experiences of Family Relationships When a Family Member Has Dementia
}

\author{
Annika Kjällman Alm, Ove Hellzen, Karl-Gustaf Norbergh \\ Department of Nursing, Mid Sweden University, Sundsvall, Sweden \\ Email: annika.kjallman@miun.se, karl-gustaf.norbergh@miun.se, ove.hellzen@miun.se
}

Received 15 April 2014; revised 22 May 2014; accepted 11 June 2014

Copyright (C) 2014 by authors and Scientific Research Publishing Inc.

This work is licensed under the Creative Commons Attribution International License (CC BY). http://creativecommons.org/licenses/by/4.0/

(c) (7) Open Access

\section{Abstract}

Approximately 66 million people worldwide will suffer from dementia in 2030. The dementia's impact affects people with the disorder and those in their social networks, most notably, their families. This study's aim was to explore the experiences of family relationships when a family member has dementia. We conducted semi-structured interviews with people diagnosed with dementia, their spouses and adult children. Seventeen participants were interviewed. All participants were recruited in open-ended ongoing structured support groups provided by a Swedish municipality in order to elicit the participants' subjective experiences on family relationships after the dementia diagnosis. Researchers used content analysis to examine the transcripts. Two main themes were identified, one relating to changed relationships where the participants experienced longing, lost closeness, loneliness and changed sibling relationships. The second theme related to supporting relationships within the family with experiences such as kinship, shared responsibilities and love and appreciation. Support should therefore focus on creating relationships and giving opportunities for conversations about changes within the families and difficult decisions, creating family or team support for those who need it.

\section{Keywords}

Dementia, Family Relationships, Next of Kin, Qualitative Study

\section{Introduction}

The 2012 World Alzheimer Report estimated that 36 million people were living with dementia worldwide in 2010, increasing to 66 million by 2030 and 115 million by 2050 [1]. In Sweden, most diagnoses are done in a primary health care setting by general practitioners, and are based on the person's own history and an Mini Mental Score Evaluation (MMSE) along with blood tests to rule out any other diseases. About 25,000 people are 
diagnosed with dementia each year in Sweden, totaling 160,000 sufferers of dementia [2]. This means that several family members are also affected by dementia.

\section{Background}

Dementia's impact affects people with the disorder and those in their social networks, most notably, their families [3]-[6]. However Roach and Keady [7] reported that, following an extensive review of the literature, they could only find one study where the researchers looked at the experience of dementia as part of a family system. Keady and Harris [8] also noted in their editorial that "people with dementia have become separated from their family systems within research, practice and policy attention with the weight of these resources being targeted at individual or dyad based methods of support/understanding” ([8], p. 6). Others have compared family caring across these different types of family relationships [9] [10]. Garwick, Detzner and Boss [11] described the search for stability and meaning for multigenerational families as a crucial marker in understanding and absorbing dementia into the family identity; it is not one person's problem, but a collective responsibility that depends on invisible strings of support within and between family members. According to the WHO report of 2012, "dementia is overwhelming for the caregivers and adequate support is required for them from the health, social, financial and legal systems" [12]. In 2009, the Swedish Parliament passed a new law that states, "Municipalities are obliged to offer support to persons caring for people with chronic illnesses, elderly people, or people with functional disabilities” [13], acknowledging the fact that family is important in daily care.

\section{Rationale for This Study}

This study aimed at exploring family relationships is part of a larger project in which we interviewed couples about their experiences in long-term ongoing support [14] as well as adult children of people with dementia to find out what it means for them to have a parent with dementia [15]. However we also had the nagging sensation they were conveying something more than what was initially asked, especially regarding how the family experienced the relationships within their family after dementia diagnose. Therefore we returned to the interviews to conduct a secondary analysis of how families experience relationships when a family member is affected by dementia. This study viewed family in the same way as our participants did, which means that siblings, aunts and uncles, children and grandchildren, and even great grandchildren are considered family.

\section{Method}

\subsection{Design}

The study had a qualitative approach exploring the participant's experiences trough interviews.

The study was conducted after approval from the Ethics Committee of the Medical Faculty, Umeå (Dnr 2011-93-31Ö). Interviewing vulnerable subjects such as those with dementia can cause emotional upset for the individual suffering from the disease. Therefore, all interviews were conducted at the support centre with staff members on hand who were familiar to the participant and able to take care of any problems. The same service was provided to adult children and partners.

\subsection{Participants}

There were 17 participants; four couples that attended a long term ongoing support group, following a referral by the physician who diagnosed mild dementia (i.e. scoring 20 or more on the MMSE) in one of the partners. The couples all lived in the area and were between 73 - 78 years old. They had no municipal service or help of any kind except for the support groups. The participants also consisted of nine adult children from an ongoing evening support group at a municipal support centre. The couples were not related to any members in the adult children group. The adult children were between 35 - 65 years old; they lived and worked in the area. All participants were approached at a support group meeting and verbally informed about the study and what it entailed. Written information and consent forms were also handed out. Informed consent was received from all participants who were then interviewed at their convenience. The study was conducted at a municipal support centre among the participants of a long-term ongoing support group. The support group is one of many at the municipal support centre, led by trained social workers that specialize in dementia care and structured according to partic- 
ipants' levels of cognitive function and content. The group receives information and education about dementia diseases in a social context.

All meetings are free of charge and held at the support centre with trained social workers as group facilitators. The meetings are held twice a month and usually last between 90 minutes and two hours, including a coffee break. The participants are a part of the group for as long as they like and can move to other groups according to need. Topics include brain function and factors that can influence function, dealing with memory loss, reminiscence, strategies to improve memory, and latest research regarding dementia.

\subsection{Data Collection}

Data was collected through interviews from October to November 2011 and March to May 2012. Data consisted of material gathered from semi-structured interviews with the participants that was digitally recorded and transcribed [14] [15]. The couples were first interviewed together; individual interviews with each took place one week after. Including persons suffering from dementia in research project can be problematic as the disease can make it difficult for the sufferer to maintain focus and find the right words in communication. However after the couples' interviews, it became clear that all interviewees would be able to share experiences relevant to the research even if they had mild dementia.

\subsection{Analysis}

The collected data were analyzed by content analysis inspired by Patton [16]. Researchers used transcribed interviews with comments regarding laughter or body language added to the transcript for clarification. Text from all participants relating to family experiences regarding changes in family relationships when a member was affected with dementia was extracted and combined into one file. This text was divided into meaning units that were condensed, abstracted, and labeled with a code to reflect the content. Then the codes were compared and, depending on content, sorted into sub-themes that were abstracted and merged into themes (see Table 1).

Table 1. Examples of analysis.

\begin{tabular}{|c|c|c|c|c|}
\hline & Condensation & Code & Subtheme & Theme \\
\hline $\begin{array}{l}\text { They have their life of course. I } \\
\text { don't know you're not that } \\
\text { necessary when you're older. }\end{array}$ & $\begin{array}{l}\text { not necessary for the } \\
\text { children }\end{array}$ & missing the children & experience of longing & \multirow{4}{*}{$\begin{array}{l}\text { Changed } \\
\text { relations within } \\
\text { the family }\end{array}$} \\
\hline $\begin{array}{l}\text { If one of the girls answered she } \\
\text { did not talk to them much, just, } \\
\text { "Hi, it's Grandma and then she } \\
\text { just asked for me." }\end{array}$ & $\begin{array}{l}\text { she just said "hi" and asked } \\
\text { for their mother }\end{array}$ & $\begin{array}{l}\text { stopped talking to the } \\
\text { grandchildren }\end{array}$ & $\begin{array}{l}\text { experience of lost } \\
\text { closeness }\end{array}$ & \\
\hline $\begin{array}{l}\text { Of course it would mean that you } \\
\text { have someone to share the } \\
\text { experience with, but if you are an } \\
\text { only child, then you're alone. }\end{array}$ & $\begin{array}{l}\text { missing someone to share } \\
\text { the experience with }\end{array}$ & $\begin{array}{l}\text { being alone with the } \\
\text { experience }\end{array}$ & $\begin{array}{l}\text { experience of } \\
\text { loneliness }\end{array}$ & \\
\hline $\begin{array}{l}\text { It works better with my sister and } \\
\text { my brothers. They do not do stuff } \\
\text { like helping mother shower and } \\
\text { that kind of stuff so they don't } \\
\text { notice. }\end{array}$ & $\begin{array}{l}\text { brothers do not notice the } \\
\text { changes }\end{array}$ & $\begin{array}{l}\text { siblings have different } \\
\text { roles }\end{array}$ & $\begin{array}{l}\text { experience of changed } \\
\text { sibling relationships }\end{array}$ & \\
\hline $\begin{array}{l}\text { It's important that you have } \\
\text { support, that you have friends but } \\
\text { especially family; aunts and } \\
\text { uncles, they kept in touch all the } \\
\text { time. }\end{array}$ & $\begin{array}{l}\text { Important with friends but } \\
\text { family is more important }\end{array}$ & family is important & experience of kinship & \multirow{3}{*}{$\begin{array}{l}\text { Supporting } \\
\text { relationships } \\
\text { within the } \\
\text { family }\end{array}$} \\
\hline $\begin{array}{l}\text { Last time my sister and I were } \\
\text { there together, in a way, we can } \\
\text { take turns talking to mother. }\end{array}$ & $\begin{array}{l}\text { visits together and take } \\
\text { turns talking }\end{array}$ & helping each other & $\begin{array}{l}\text { experience of shared } \\
\text { responsabilities }\end{array}$ & \\
\hline $\begin{array}{l}\text { You see, he still gets over the } \\
\text { moon when the girls visit, and that } \\
\text { is important. }\end{array}$ & $\begin{array}{l}\text { overjoyed when the girls } \\
\text { come home }\end{array}$ & $\begin{array}{l}\text { happy when the girls } \\
\text { come }\end{array}$ & $\begin{array}{l}\text { experience of love and } \\
\text { appreciation }\end{array}$ & \\
\hline
\end{tabular}


Themes were identified that described the underlying meaning of the content [17]. To ensure rigor in data analysis, all authors were involved in the analysis. Then they met to compare notes and discuss their analyses until consensus regarding the findings was reached.

\section{Findings}

The analysis showed that the relationships within the families experienced both positive and negative ways as the two themes show. The two themes are: 1) changed relationship within the family with subthemes of experience of longing, experience of lost closeness, and experience of loneliness and experience of changed sibling relationship; 2) supporting relationships within the family included subthemes of experience of kinship, experience of shared responsibilities, and experience of love and appreciation.

\subsection{Changed Relationship within the Family}

\subsubsection{Experience of Longing}

Experience of longing was expressed by healthy partners and adult children. For healthy partners it had to do with children leaving for work in other parts of the country. "Yeah, the grandchildren and our son took good care of us, but he moved and now we have no one." They also said siblings to the person with dementia longed for their brother or sister as they were before the disease and found it hard to cope with the changed relationship. "Her sister gets upset and sad every time she comes. I tell her not to come if it upsets her. It's hard for her since she sees the difference clearer when she only visits a few times a year."

Both the dementia patient and their healthy spouse longed for their children and grandchildren and said they would like to see them more often. "We have good kids and we love them so very much and it's nice to hear from them." "I long for my daughter to visit, I love her very much."

The partner suffering from dementia also longed to help their family more but knew of their limitations due to the disease. "and they have theirs of course.... I don't know... you're not that necessary when you get older." "I would like to help with what little I can but I cannot do any miracles...no way.” They also wanted a closer connection with their siblings but were limited to phone conversations with their siblings due to distance and disease. "Bert's sister lives so far away so they don't see each other very often, unfortunately. They speak on the phone, mostly."

\subsubsection{Experience of Lost Closeness}

The experience of lost closeness included difficulty communicating with children, grandchildren and parents affected by the disease. “And I remember the girls saying, 'Grandma never talks to us anymore.”, Children who did not keep in touch after the dementia diagnosis as well as grandchildren who found it hard to talk to their grandparents because of the dementia said, "She asks for my little brother, her youngest son, who has only visited her once after I forced him into going," Or "My oldest, she's been with me a couple of times but she doesn't want to come. No, she doesn't... sometimes she's... for Christmas she was there helping out, but otherwise she feels she has nothing to talk about with Grandma." Lost closeness was also expressed by the persons with dementia that missed being close to their grandchildren and felt that the previous connection and closeness was not there. Some of the adult children said the personality changes in dementia sufferers where the affected person became aloof and disinterested left them feeling disconnected. "It's just awful really... how everything can be erased... before, she knew all the birthdays of all her children and grandchildren. No, no and it's like she doesn't even care now, before she always got them something or just some money in an envelope but now nothing... so it's sad in a way.”

The adult children said it was hard for them to see their children disconnecting themselves from their grandparents, withdrawing and not visiting or talking to them anymore. "They were always at her house before but now... it's so sad." The adult children also said it was hard to see that their diseased parent forgot the names of their grandchildren and did not recognize them if and when they visited. Sometimes they even forgot that they had grandchildren. "She doesn't remember the grandchildren anymore. When my youngest comes home and visits, she thinks it's her son. She never had a son, she only has me.”

\subsubsection{Experience of Loneliness}

Adult children without siblings expressed their loneliness by wishing they had siblings to share the experience 
with and with which they could make decisions. They said they felt truly alone for the first time in their life. "Of course if you have siblings you have someone to share the experience with emotionally but if you're an only child... you're alone," or "My partner was there for me but it's not his parents, even if he likes them, so it's like you have no one to share the responsibility with. I never missed having siblings when I was younger but now, I do." The person affected by dementia also expressed loneliness in terms like they were the only ones left, that their siblings were all dead. "There were six of us but it's just me now."

\subsubsection{Experience of Changed Sibling Relationship}

With experience of changed sibling relationship, the adult children expressed jealousy toward one of their siblings who, in their mind, had a better or closer connection with the affected parent. "My sister has a better hand with mother. Whenever I do something she can swear and curse, but with my sister she never does that." They also gave examples that one of the sibling's roles differed or that they took on more responsibility than others. "My sister does OK with taking care of mother and having her shower. My brothers never do that, so they don't notice the small changes." They were also treated differently by their diseased parent. "No, she would not sign the paper, both me and my sister tried. But when our brother just said, 'sign here,' she did." There were also changes in how the siblings got together. "We always celebrated holidays together, all us siblings with families but we can't do that now. We tried a couple of years ago and it was a disaster; mother was beside herself and wanted to leave. We had to convince her to stay and at least have something to eat, after all it was Christmas."

\subsection{Supporting Relationships within the Family}

\subsubsection{Experience of Kinship}

The adult children described their aunts and uncles as supportive and helping out when needed. "It was lucky that my aunt and uncle could come up and help. If they hadn't done that, then..." and "It's so important to have good family. It's important to have someone to talk to and to help guide you in your decisions... They are amazing that way." Dementia sufferers siblings who, despite their own poor health, made the trip to see their sibling, "Both her sisters' visits sometimes, one lives further south and has problems with her knees so she doesn't visit often, but the other one she visits more often." People affected by dementia said their children did everything to help them and they felt supported by their children. "Our son helped us with everything practical, cleaning the garage and things like that" and "I can always call my son when his father was being difficult, he's a great support." Kinship was expressed by all as the sense of sharing an experience of dementia especially in families with a hereditary form of dementia, where uncles could tell the story of their mother being affected by Alzheimer's, an experience the adult children could share with their aunts and uncles across generations. "The weird part is that when we started talking about it in the hospital, it started exactly the same way with their mother, so we could share experiences."

\subsubsection{Experience of Shared Responsibilities}

The adult children discussed how they all cared for their diseased parent and supported their healthy parent, taking care of different aspects of care or dividing different chores between them. "For a couple of months me and my sister took turns living at home with our parents," and "It's nice, we help each other out, but my oldest brother usually handles medical situations. I handle more practical stuff regarding clothes and food. We divided it that way."

They also helped each other out in keeping the family together and facilitating contacts between their diseased parent and their children-grandchildren to the diseased. "I usually call my son or daughter when I am at mothers so she could talk to them" and "We usually go and see mother together now; me, my daughter and her kids. She finds it too hard to speak to mother on her own."

\subsubsection{Experience of Love and Appreciation}

In the subtheme experience of love and appreciation, both the dementia sufferer and their healthy partner expressed joy over the grandchildren, wishing them all the best and enjoying every moment they could spend with them. They enjoyed the connection they felt and also expressed their appreciation over children and grandchildren and how well they all got along. They looked forward to hearing from children and grandchildren and seeing them again. "We have always got along fine, we have three girls and there where never any problems. He is 
still over the moon every time they come home," and "They play poker together when he sees the grandchildren. He is really enjoying himself. 'Now you lose Grandpa,' they say, and he just laughs.”

The adult children also said their children wished to see their grandparent suffering from dementia when they came home to visit. "He always visits when he's home although it makes him sad; he feels that it is important to connect." In other families, the grandchildren found Grandma and Grandpa's presence for Christmas very important, because otherwise there was no Christmas. "Our oldest grandchild is driving up to get us back to their place and the family for Christmas. He and his sister want us there for the holidays."

\section{Discussion}

The aim of this study was to explore and describe the experiences of family relationships when a family member has dementia. The findings showed a duality because the families' bonds were both changed and supported. By nature human beings are drawn toward interpersonal connections, and the earliest and most sustaining is with our family [18] Therefore it is no wonder we are so affected by changes within the family and we react in different ways, some pulling together and others pulling away. Walters, Oyebode and Riley [19] study showed that some of the caregivers had re-drawn relational boundaries, positioning dementia at the heart of their definition of relationship stating that they did not feel the same way about their spouse as they used to. Other studies show that despite the previous relationships within the family, it can change for the worse when a family member is affected by mild or moderate dementia [20] [21].

In the theme changed relationship within the family, the interviewees described the changes as longing, loss of closeness, loneliness and changed sibling relationships, indicating that the participants struggled with everyday family life after diagnosis. Studies show that the changes in the sufferers' personality after the diagnosis are especially hard for the next of kin and adult children to handle [2] [22]-[24]. The changes in relationships and the balance of relationships can be especially distressing [25]. In a study by Garwick, Detzner and Boss [11] families spoke little about the medical symptoms associated with dementia and instead focused their attention on "how the disease disrupted the fabric of everyday family life" (p. 8). In the present study the difference between male and female adult children in terms of how they are treated by their parent is shown both by the quotation that the son helped with practical things and the statement about the parent signing papers only after the son asked, and not the daughters. Liedstrom, Kihlgren, Skovdahl and Windahl [26] found that female next of kin was more emotionally invested than male care givers but also more disappointed with the care receiver.

Being an only child of a person affected by dementia can make the individual long for a family and wish to have siblings they could discuss the situation with and support them in decisions. Sibling relationships are the longest lasting of our lives. Siblings come before friendships or romantic relationships, and usually outlive our parents [27]. Addis and Tippett [28] showed in their study that the recall of childhood memories was better than recall of adulthood in persons diagnosed with dementia than in the control group without dementia. Therefore the loneliness expressed by the people with dementia in this study can be understood; losing your siblings that they can share childhood and youth memories with when the memory is failing could be like losing yourself.

Goffman [29] said a group of individuals that collaborates in a representation can assume different roles where each team member depends on other members to perform their role. Each team member must have three qualities if their team is to operate in a sufficient manner: loyalty, discipline and caution using discretion in their social engagement [29]. The definition above could be applied to a family or a team as we see in the theme supporting relationships within the family, where the interviewees expressed kinship, shared responsibilities and love and appreciation. Supporting family members in continued relationships despite the disease also shows adaption of everyday life within the family affected by dementia and assigning new roles for the team members. A study by Garwick, Detzner and Boss [11] showed that dementia can have a disorganizing influence on family roles and boundaries; a reallocation of roles and responsibilities takes place within the family. This upheaval of steady state can be viewed as a crisis. This can be handled if the individuals adapt their current behavior, their effect, and their understanding of the crisis. This will allow them to build on their ego strengths and the resources available to them, creating a stronger team [30].

Supporting relationships within the family shows that not only have the families adapted but they also found meaning in the situation. Loving and caring for someone despite a debilitating disease is a way for the family to cope and find meaning. Frankl [31] described meaning as "by experiencing something—such as goodness, truth or beauty—by experiencing nature and culture or, last but not least, by experiencing another human being in his very uniqueness-by by loving him” ([31], p. 111). Frankl’s quote [31] ties in with Keady and Harris [8] defini- 
tion, “care-giving is not all about 'stress,' 'coping' and 'burden' and is, perhaps, and more fittingly, about human commitment, care, warmth, love and devotion” ([8], p. 5). All the things we usually associate with family. It seems to be easier to cope with the changes in the relationships and create supporting relationships in larger families where there are more family or team members around the diseased. Single children with no siblings struggle more with the situation and feel the need for sibling support or support from kin in their decision making process. However there are limitations since this is a small qualitative study with few participants and more research is needed to further explore these connections. All participants lived in close proximity to each other, which supported their family relations. Adult children moving to the southern part of Sweden for work are common, and three of the couples had children who moved but this study does not explore those effects on family relations. Only two participants in the adult children group could be said to belong to the sandwich generation, others had grown up children and own grand children.

\section{Conclusion}

All family members should be offered support for the partner and/or care-giving adult child. Grandchildren are also affected and should be included or have specialized information about the disease and how to communicate with grandparents affected by dementia. Support should focus on creating relationships between members of the support group and giving opportunities for conversations about changes within the families and difficult decisions, creating family or team support for those who need it and maintain relationships between family members.

\section{References}

[1] Batsch, N.L. and Mittelman, M.S. (2012) World Alzheimer Report 2012. “Overcoming the Stigma of Dementia”. Alzheimer’s Disease International. http://www.alz.co.uk/research/WorldAlzheimerReport2012.pdf

[2] SBU—The Swedish Council on Health Technology Assessment (2006) Demenssjukdomar—En systematisk litteraturöversikt (in Swedish).

[3] Orange, J.B. (1991) Perspectives of Family Members Regarding Communication Changes. In: Lubinski, R. and Orange, J.B., Eds., Dementia and Communication, B. C. Decker, Hamilton, 168-186.

[4] Small, J.A., Geldart, K. and Gutman, G. (2000) Communication between Individuals with Dementia and Their Caregivers during Activities of Daily Living. American Journal of Alzheimer's Disease and Other Dementias, $15,291$. http://dx.doi.org/10.1177/153331750001500511

[5] Brewer, J. (2005) Carousel Conversation: Aspects of Family Roles and Topic Shift in Alzheimer's Talk. In: Davis, B., Ed., Alzheimer Talk, Text, and Context, Palgrave MacMillan, Basingstoke, 87-101.

[6] Savundranayagam, M., Hummert, M.L. and Montgomery, R.J.V. (2005) Investigating the Effects of Communication Problems on Caregiver Burden. Journal of Gerontology, 60B, S48-S55. http://dx.doi.org/10.1093/geronb/60.1.S48

[7] Roach, P. and Keady, J. (2008) Young People with Dementia: Time for Fair Play. Comment Piece. British Journal of Nursing, 17, 690. http://dx.doi.org/10.12968/bjon.2008.17.11.29604

[8] Keady, J. and Harris, P.B. (2009) Family Matters. Dementia: The International Journal of Social Research and Practice, 8, 3-8. http://dx.doi.org/10.1177/1471301208099042

[9] MacRae, H. (2002) The Identity Maintenance Work of Family Members of Persons with Alzheimer's Disease. Canadian Journal on Aging, 32, 405-415. http://dx.doi.org/10.1017/S0714980800001720

[10] Lee, Y. and Smith, L. (2012) Qualitative Research on Korean American Dementia Caregivers’ Perception of Caregiving: Heterogeneity between Spouse Caregivers and Child Caregivers. Journal of Human Behavior in the Social Environment, 22, 115-129. http://dx.doi.org/10.1080/10911359.2012.646840

[11] Garwick, A.W., Detzner, D. and Boss, P. (1994) Family Perceptions of Living with Alzheimer's Disease. Family Process, 33, 327-340. http://dx.doi.org/10.1111/j.1545-5300.1994.00327.x

[12] WHO (2012) Dementia: A Public Health Priority. http://whqlibdoc.who.int/publications/2012/9789241564458_eng.pdf

[13] Swedish Social Services Act. (2009) Law 2009: 549. http://www.riksdagen.se/sv/DokumentLagar/Lagar/Svenskforfattningssamling/Socialtjanstlag-2001453_sfs-2001-453/? bet $=2001: 453$

[14] Kjallman Alm, A., Hellzen, O. and Norbergh, K.-G. (2013) Experiences of Long Term Ongoing Structured Support in Early Stage of Dementia-A Case Study. International Journal of Older People Nursing. 
http://dx.doi.org/10.1111/opn.12034

[15] Kjallman Alm, A., Norbergh, K.-G. and Hellzen, O. (2013) What It Means to Be an Adult Child of a Person with Dementia. International Journal of Qualitative Studies on Health and Well-Being, 8. http://dx.doi.org/10.3402/qhw.v8i0.21676

[16] Patton, M.Q. (2002) Qualitative Research and Evaluation Methods. 3rd Edition, Sage Publications, Thousand Oaks.

[17] Ryan, G.W. and Russell Bernard, H. (2003) Techniques to Identify Themes. Field Methods, 15, 85-109. http://dx.doi.org/10.1177/1525822X02239569

[18] Marshall, A., Bell, J.M. and Moules, N.J. (2010) Beliefs, Suffering, and Healing: A Clinical Practice Model for Families Experiencing Mental Illness. Perspectives in Psychiatric Care, 46, 197-208. http://dx.doi.org/10.1111/j.1744-6163.2010.00259.x

[19] Walters, A.H., Oyebode, J.R. and Riley, G.A. (2010) The Dynamics of Continuity and Discontinuity for Women Caring for a Spouse with Dementia. Dementia, 9, 169-189. http://dx.doi.org/10.1177/1471301209354027

[20] Vellone, E., Piras, G., Talucci, C. and Cohen, M.Z. (2007) Quality of Life for Caregivers of People with Alzheimer's Disease. Journal of Advanced Nursing, 61, 222-231. http://dx.doi.org/10.1111/j.1365-2648.2007.04494.x

[21] Peisah, C., Brodaty, H. and Quadrio, C. (2006) Family Conflict in Dementia: Prodigal Sons and Black Sheep. International Journal of Geriatric Psychiatry, 21, 458-492.

[22] Strang, V., Koop, P., Dupuis-Blanchard, S., Nordstrom, M. and Thompson, B. (2006) Family Caregivers and Transition to Long-Term Care. Clinical Nursing Research, 15, 27-45. http://dx.doi.org/10.1177/1054773805282356

[23] Harman, G. and Clare, L. (2006) Illness Representation and Lived Experience in Early-Stage Dementia. Qualitative Health Research, 16, 484-502. http://dx.doi.org/10.1177/1049732306286851

[24] Laakkonen, M.L., Raivio, M., Eloniemi-Sulkava, U., Saareneheimo, M., Pietilä, M., Tilvis, R.S. and Pitkälä, K.H. (2008) How Do Elderly Spouse Care Givers of People with Alzheimer's Disease Experience the Disclosure of Dementia Diagnosis and Subsequent Care? Journal of Medical Ethics, 34, 427-430. http://dx.doi.org/10.1136/jme.2007.021956

[25] Quinn, C., Clare, L., Pearce, A. and van Dijkhuizen, M. (2008) The Experience of Providing Care in the Early Stages of Dementia: An Interpretative Phenomenological Analysis. Aging and Mental Health, 12, 769-778. http://dx.doi.org/10.1080/13607860802380623

[26] Liedström, E., Kihlgren, A., Skovdahl, K. and Windahl, J. (2014) Being a Next of Kin-Experiences of Burden and Quality of Life. Open Journal of Nursing, 4, 275-286. http://dx.doi.org/10.4236/ojn.2014.44032

[27] Pike, A., Coldwell, J. and Dunn, J. (2009) Siblings-Friends or Foes? Childhood, 22, 494-497. http://www.thepsychologist.org.uk/archive/archive home.cfm/volumeID 22-editionID 176-ArticleID 1518-getfile ge tPDF/thepsychologist\%5C0609pike.pdf

[28] Addis, D.R. and Tippett, L. (2010) Memory of Myself: Autobiographical Memory and Identity in Alzheimer’s Disease. Memory, 12, 56-74. http://dx.doi.org/10.1080/09658210244000423

[29] Goffman, E. (2004) Jaget och maskerna. Rabén \& Sjögren, Elanders Infologistics Väst AB (in Swedish).

[30] Loughran, H. (2011) Understanding Crisis Therapies: An Integrative Approach to Crisis Intervention and Post-Traumatic Stress. Jessica Kingsley Publishers, London.

[31] Frankl, V.E. (2006) Man’s Search for Meaning. Beacon Press, Boston. 